\title{
Tolerance as the Essential Key for Javanese Society in Preserving the Traditional Cultures
}

\author{
Najmu Tsaqib Akhda \\ STAI Sunan Pandanaran, Yogyakarta \\ email:najmuakhda@gmail.com
}

\begin{abstract}
The close relationship between Java and syncretism invites many questions regarding the historical and cultural backgrounds of these two elements. This paper attempts to find out the form of relationship made by the Javanese society and the practice of syncretism. Some literary reviews are presented in portraying the connection of the Javanese society, especially the practices related to Islam, and the practice of syncretism. It is found out that tolerance is the essential key in accommodating Javanese society and syncretism. Indeed, the era of globalization and modernization is one of the challenges in preserving Javanese traditional cultures.
\end{abstract}

\section{Keywords:}

Syncretism, Javanese-culture, Tolerance

\section{Introduction}

Due to its close relationship with Islam, Javanese culture is known as one of the most unique cultures in Indonesia. The unique characteristic of Javanese culture invites question on whether Islam in Java is different from Islam in general. If it is different, there are two possible aspects which influence the condition: (1) the "mystic synthesis" or the syncretism as the result of Javanese culture, or (2) the particular historical conditions. The other questions are whether the abangan and priyayi, categorized by Geertz (1960), in the post-Suharto era have been disappeared, and whether Java is still tolerant or fundamentally polarized? The answers to 
these questions can explain the relationship of Java and syncretism seen from the historical, cultural, as well as social and religion aspects.

Islam in the Javanese society, however, presents various groups in which each of the group represents its particular thought. These variants are not only common in the past but also ordinary in the contemporary Javanese Islam. Several categories to fill in the variants have been identified by some scholars, i.e. santri-abangan (devout-nominal) Islam (Geertz 1960), orthodox-heterodox Islam (Federspiel 1970, 3), traditionalist-modernist Islam(see Geertz 1960), structural-cultural Islam (Afandi 1996), politicalcultural Islam (Nasih 2003), scriptural-substantial Islam (Effendy 1994), reformist-conservative Islam (Saleh 2001, 2-3) and liberal-fundamental Islam (Abshar-Abdalla et al. 2003; Effendy 2001, 76). These variants of Islam have simultaneously developed and still evolve within the country (Muzakki 2010, 260).

Islam in the Javanese society is different from the Muslim World. Indeed, Java is unique for its cultures and places. The uniqueness emerges as a result of a social interaction between the Javanese people and the outsiders. Based on the history, the outsiders came to Java for trading due to its fertile land. Thus, Java is called as a gemah ripab loh ji nawi land. Some scholars, such as Clifford Geertz, Ricklefs, Anderson, Reid writes about Java and its culture to describe the life of Javanese. Historically, Javanese people lived with their own cultures and traditions. Then, Hinduism and Buddhism came in age of commerce.(Geertz 1976; Ricklefs 2007; Anderson 2009). As a result, Javanese people started to embrace Hinduism and Buddhism. In $15^{\text {th }}$ century, Islam came to Java and people began to recognize Islam.

Javanese people are easy to adapt with new culture, especially when the new culture is considered as good for them. There were negotiation and accommodation between Javanese people and those who brought

1 Gemah ripah loh ji nawi: a Javanese slogan which represents a very fertile land. 
Islam to the land. Besides, there were also dialogues between the local culture and Islam as the new culture.

Basically, a new culture will be received by Javanese people because they are very flexible in receiving good values from other cultures. This phenomenon becomes a special characteristic and, as a consequence, affects the behavior and habit of Javanese people. Javanese people have experienced a long cultural process in building their civilization. This cultural process includes a dialogue phenomenon between the new culture and local culture.

When Islam came to Java, Islam also interacted with the local culture and the indigenous tradition. This phase was a very sensitive process for the society. During the dialogue, Islam and the local tradition were placed in an equal position. The combination of religion and society is a realism of local exegesis so that religion will not appear as an empty element in reality.

\section{Dialogue as a Form of Negotiation}

The dialogue between Islam and the local tradition was held with the spirit of negotiation. Negotiation is a process to discuss something and interpret it with the intention of looking for new things. In the cultural context, a society has a capability to negotiate a particular case based on the applicable rules. On the other words, negotiation is a part of cultural transformation in every cultural move. The process of negotiation is a creative process which is accommodated with cultural spirit. Therefore, the migrants and local people are in the same position.

From this cultural companionship between Islam and Javanese culture, Javanese people received the new tradition because the local society indicated the good values in Islam. Another reason is the kingdom role from the Javanese kings. One of the examples is in Walisanga ${ }^{2}$ case.

2 Walisanga: nine pious people who had a historical role in the spread of Islam in Java. 
Walisanga used cultural approach to spread Islam. Their success was due to their genius strategy in adopting the local culture and Islam. Besides, they were also moderately involved within the formal authorities. They adapted Islam with the local tradition and culture until the people accepted Islamic doctrines without any compulsions. They also collaborated with the local governments with the purpose of effectively managing the people under the regulations affected by Islamic doctrines.

\section{Acculturation of Islam and Javanese Society}

Islam in Java is different from the Muslim World in general. Generally, Middle East countries, as the center of Islamic civilization, have Islamic government, Islamic Law and other Islamic characteristics. Javanese people accepts the Islamic rituals and it defines that Islam in Javanese society is part of the worldwide Muslim community (Ricklefs 2007, 233; Van Den Boogert 2017; Kuipers \& Askuri 2017; Maftukhin 2016; Hefner 2013). Furthermore, Javanese Muslims of this period see themselves as part of a wider Islamic world. Javanese personal and family life are marked by many recognizable Islamic rituals, such as fasting, burial, prayer, and the hajj (Ricklefs 2007, 224; Sahlan \& Fatchan 2016).

However, Islam in Java is characterized by the acculturation of Islam and the tradition. Thus, it creates Javanese Islam. Islam in Java has strong connection with mysticism and Javanese culture. Javanese people perform slametan, ziarah kubur, hajj, and other traditions ${ }^{3}$. These activities cannot be found in other countries. However, Javanese Islam has the same characteristics with Islam in general because there are many religious scholars (Ulama) who build Pesantren ${ }^{4}$ and other formal schools. These

3 Slametan is a communal event in Java reflecting the unity of the participants.

4 In a more detailed way, pesantren represents a mode of religious-based schooling system typical of Indonesia which characteristically has five components: the cleric, the students (or referred to as santri), the mosque, a boardinghouse and the classic books (or referred to as kitab kuning). 
activities are represented by two biggest Islamic organizations, Nahdlatul Ulama' and Muhammadiyah (Dhofier 1980). Both of these organizations bring new color to Islam in Java maintaining the good old values.

This mystic synthesis makes the reconciliation of social and philosophical elements possible. However, in other circumstances, the mystic synthesis has been thought to be a contradictory. A philosophical position viewing the phenomenal world as unreal and the divinity as immanent is reconciled with a religion seeing the world as a real creation of a God who is transcendent. The reconciliation was achieved by maintaining the philosophy and adopting the outers' symbols, rituals, and (rather selectively) the law of the later (Ricklefs 2007, 225).The firm Javanese-Islamic identity admitted the reality of local spiritual forces of non-Islamic origin (Ricklefs 2007, 222). Based on Islamic tradition, the God is only Allah. Consequently, the local traditions initiated with the local spirit were replaced with the Islamic values underlying the faith in Allah and Prophet Muhammad. Furthermore, the religious scholars in Java performed preaching activities by upholding calm and respect to the society so that they were received by the society.

Javanese "mystic synthesis" or syncretism is a result of Javanese culture and particular historical conditions. In Javanese society, there is King's authority which creates a "mystic" among society. From this phenomenon, a new "mystic" emerged with the aims of establishing peace and society trust to the kingdom. By following a religious interest, a King can control the citizen. Although the wars between Islam and Hindu and Buddhist kingdoms were taken place, but the wars tend to be caused by the economic and political problems, rather than merely caused by religious interest. After Islam defeated Hindu and Buddhist kingdoms, they built new social identity in the middle of the society. It is now possible that advancing Islamization will represent a threat to the established hierarchy in Java (Ricklefs 2007, 68). 
After spreading of Islam in Java, the society tried to adapt the new value and implemented the former and new values. Within the new Islamic value, people shared their mystic experiences and created a new "mystic synthesis". The various rituals in Java were replaced with Islamic value, mainly by the roles of Walisanga. Walisanga gave a new understanding about religious practices in Java, such as Wayang (puppet), worship place, and other traditions in Javanese society. Walisanga succeeded in forming new "mystic synthesis" in Javanese society. They did not only give other perspectives about traditions and rituals, but they also gave new values which were related with the society needs. After Walisanga era, Islam in Java with new "mystic synthesis" started to spread to all areas in Indonesia and, thus, it became the dominant Javanese identity (Ricklefs 2007, 221).

In the late nineteenth century, the mystic synthesis faced serious challenges and ceased to be the dominant mode of identity for Javanese people. Around1850s, the Islamic society in Java began to divide itself into two communities: wong putihan (white people) who identified themselves as devout Muslims, and wong abangan (red or brown people) who considered Islam as a less significant aspect in their life (Ricklefs 2007, 230). These two categories emerged as there was a social interaction in the middle of the society. Another category is classified by Geertz: santri, abangan and priyayi.

After the independence of Indonesia, people in Java started to life with the new culture, including in the economic, politics, and religion. Geertz develops a thick description theory to interpret cultural transitions in Java. Geertz succeeds in elaborating the Javanese culture based on the social, economic, religion, cultural and political discourses. He divides people in Java into three groups; abangan, santri, and priyayi (Geertz 1976:5). Abangan tend to be close to people in the rural area and PKI (Indonesia communist party). While santri ${ }^{5}$ are the pious people who join the Masjumi

5 The term 'santri' has, sociologically, at least two meanings: student of 
(Islamic Party); and Priyayi is the government and elite people who join with PNI (Indonesia National Party).

The abangan and priyayi categories have disappeared in the postSuharto era. In 1952, The Ministry of Religions (which later becomes the Ministry of Religious Affairs) proposed a restricted definition of religion. The idea at the core of this course of action is: to be legitimated as an 'official' religion, a particular religion should have a prophet and a holy book, and also be widely acknowledged internationally. In 1961, the Ministry of Religious Affairs again proposed the perimeter of religion (agama in Indonesia) that vindicates equal validity gestured in the previous propositions. Religion as authorized by the Indonesian state includes requirements as follows: (1) it is an encompassing way of life with concrete regulations, (2) it teaches about the oneness of God; (3) it has a holy book, which codifies a message sent down to prophet(s) through a holy spirit; and (4) it is led by a prophet. That the state views all religions outside these limitations as 'tribal' beliefs, and are therefore 'superstitious', is the working framework of this discourse (Hidayah 2007, 5). This policy caused the dichotomy blurred. Indeed, the political party policy formed three legal political parties, i.e. PPP, Golkar and PDI.

After the fall of Soeharto, Indonesia entered a reformation era and became more "democratic". In the reformation era, there were 35 parties and people were free to become what they wanted. People from the rural

traditional pesantren and devout Muslim. There is an intimate connection between the former meaning and the latter in the sense that by being enrolled as a student of traditional pesantren, one can direct him/herself to become a devout Muslim, as pesantren has long represented the best place for the study of religious teachings. In modern times this is no longer the case as pesantren does not appear to be the only place for the study of religion. There are several forums in which Muslims can go for studying their religion and lead themselves to become devout Muslims, such as MajelisTalim (socio-religious gathering for Islamic studies) and halaqah (religious circle). In particular reference to the meaning of santri as devout Muslim, Clifford Geertz (1960) popularizes the term as a social entity within Javanese society in comparison to the other that is abangan (nominal Muslim). 
areas could study at universities and increased their status. People from the cities who studied in pesantren became pious people. Santri who joined certain party became politic actor. Geertz demonstrates the situation in Javanese society. First, there is a great deal of antagonism between the adherents of the various religious orientations(Geertz 1976, 355). Second, Javanese share many common values which tend to counteract the divisive effects of variant interpretations of these three values. Third, there are several factors which tend to exacerbate conflict among the three groups and several others tend to moderate them. This kind of situation creates religion and social conflict, including: ideological, class, and political conflict. Besides, there is also religion and social integration from the social mechanism of common value.

\section{Tolerance in Javanese Society}

Since the independence of Indonesia, it has become popular to speak about "tolerance". Whether or not the Javanese themselves traditionally regarded tolerance as one of their salient ethnic traits, nowadays they are likely to take a quiet pride in their reputation for broadmindedness (Anderson 2009, 15; Crouch 2013; Hefner 2009). According to Javanese culture, it can be seen that Javanese people are still tolerant as the people keep the social norm, like tolerance especially people who live in the village. Tolerance can be seen in the activities which involve all members of the society, like the traditions of burial, birth, selametan, etc. Different opinions among the society occur usually during the village leader election or other direct election but this difference is not a permanent phenomenon.

In the classic opposition between santri and abangan groups, "tolerance" is basically a weapon to deny ascendancy to the santri and assure the continued legitimacy of traditional abangan domination (Anderson 2009, 15). However, in the society, all people including the children, adults, women, and men hold the social norm in order to keep the relationship 
among them. It is not simply out of nostalgia that an attempt has been made here to discuss the problem of Javanese tolerance.

According to Afdal, being tolerant is considered important by most people. Tolerance is also about navigating the differences in the society societies where neighbors, colleagues, groups of people, even children and spouses are of different opinions and live in a different way (Afdal 2010, 259; Hoon 2017; Crouch 2017; Huijgh 2017). The process of identifying it often leads to confusion and disagreement. Therefore, tolerance is often understood as a liberal value. The assumption that tolerance is a liberal value only is identified by three different conceptions of tolerance: tolerance as forbearance, tolerance as being unprejudiced, and tolerance as openness.

It is out of an instinctive conviction that tolerance in all human communities is a highly fragile thing, especially a tolerance which is not simply an ignoring of non-conformities that do not threaten us or impinge directly on our lives, but which springs from a genuine respect for human variety and human personality as such (Anderson 2009, 15). In the sense of Javanese society, people are very tolerance to one another although they have different religion.

Anderson argues that out of a deep awareness of the complex inter-relatedness of human existence, traditional Javanese civilization develops a style of ethic, morality, and philosophy, best expressed in wayang, which helps to give each man a sense of his own dignity and honor. The ethic, morality, and philosophy also help people to sustain and legitimize tolerance (Anderson 2009, 45).

Considering the aforementioned historical and sociocultural elaboration, the challenges are the globalization and modernization. Javanese society will probably lose its identity unless the people keep the tolerance as their way of life. 


\section{Conclusion}

There is a strong relationship between Islam and syncretism in Javanese society. The ancestors of Javanese people accepted Islam as part of their way of life due to the genius strategies applied by walisanga which always accommodated cultural values within Islamic teachings. Thus, Javanese people were easy in receiving Islam as the new religion at that time.

As Javanese culture is known as a flexible society in accepting new culture, there were acculturations as well as assimilation in the practice of Islamic rituals. Hindus and Buddhist rituals which occupied Javanese society before the spreading of Islam would then influence the practice of Islamic rituals. Thus, there are some traditions in Javanese culture which accommodates the nuance of Islam and the former religions, such as selametan, and other ceremonial celebration (i.e. burial, birth, etc.).

It can be concluded that the close relationship between Islam and syncretism can be seen from the historical as well as cultural aspects. The blending between the new and the former culture successfully creates tolerance within the society. The challenge for the Javanese people is then the globalization and modernization. 


\section{References}

Afdal, Geir. 2010. “The Maze of Tolerance.” In International Handbook of Inter-Religious Education, 597-615. London: Springer.

Anderson, Benedict. 2009. Mythology and the Tolerance of the Javanese. Equinox Publishing.

Crouch, M. 2013. Law and Religion in Indonesia: Conflict and the Courts in West Java. London: Routledge.

Crouch, M. 2017. The Expansion of Emergency Powers: Social Conflict and the Military in Indonesia. Asian Studies Review 41 (3), pp. 476493.

Dhofier, Zamakhsyari. 1980. "The Pesantren Tradition: A Study of the Role of the Kyai in the Maintenance of the Traditional Ideology of Islam in Java." The Australian National University.

Geertz, Cliffford. 1976. Religion of Java. London: University of Chicago Press:

Hefner, R.W. 2009. Islamic Schools, Social Movements, and Democracy in Indonesia in Making Modern Muslims, pp 55-105.

Hefner, R..W. 2013. Islamization and the Changing Ethical Imagination in Java. Indonesia 2013 (96 Special Issue), pp. 187-202.

Hoon, C.Y. 2017. Putting Religion into Multiculturalism: Conceptualising Religious Multiculturalism in Indonesia. Asian Studies Review 41 (3), pp. 459-475.

Huijgh, E. 2017. Indonesia's “Intermestic" Public Diplomacy: Features and Future. Politics and Policy 45 (5), pp. 762-792.

Kuipers, J.C., Askuri. 2017. Islamization and Identity in Indonesia: The Case of Arabic Names in Java. Indonesia 2017 (103), pp. 25-49.

Maftukhin. 2016. Islam Jawa in Diaspora and Questions on Locality. Journal of Indonesian Islam 10 (2), pp. 375-393.

Muzakki, Akh. 2010. "Islam as a Symbolic Commodity, Transmitting and Consuming Islam through Public Sermons in Indonesia." In Religious Commodification in Asia, Marketing God, edited by Pattana Kitiarsa. London: Routledge groups.

Ricklefs, M.C. 2007. Mystic Synthesis in Java. WastBridge: Norwalk. 
Sahlan, A., Fatchan, A. 2016. Collaboration Sufism Islamic and Adherents Javanese in the Story Puppet of Dewaruci in Java Indonesia. Social Sciences (Pakistan) 11 (21), pp. 5211-5217.

S, Hidayah. 2007. "How the World Would Have to Be If There Is No 'Agama' in Indonesi." CRCS.

van den Boogert, J. 2017. The Role of Slametan in the Discourse on Javanese Islam. Indonesia and the Malay World 45 (133), pp. 352-372. 